\title{
Inheritance of Enzymes and Blood Proteins in the Leopard Frog, Rana pipiens: Three Linkage Groups Established
}

\author{
David A. Wright, ${ }^{1}$ Christina M. Richards, ${ }^{2}$ and George W. Nace $^{2}$
}

Received 25 July 1979-Final 24 Oct. 1979

Individuals from natural populations of the leopard frog, Rana pipiens, were analyzed for electrophoretic differences in blood proteins and enzymes from an amputated digit. The proteins examined represent products of 72 loci. Presumptive heterozygotes at multiple loci were selected for experimental crosses. Mendelian inheritance of 18 protein variations were demonstrated in the offspring. Tests for linkage or independent assortment were performed for 75 locus pairs. Three linkage groups were established. Linkage group 1 contains two loci, aconitase-1 (Acon1) and serum albumin (Alb), with a 19\% recombination frequency between them. Linkage group 2 contains four loci, glyoxalase (Gly), acid phosphatase-1 (Ap1), acid phosphatase-2 (AP2), and esterase-5(Est5). The data show the relationships Gly-21.1\%-AP1-0\%-AP2-6.3\%-Est5, and Gly-25.6\%-Est5. Linkage group 3 consists of four closely linked esterase loci. The data, Est $1-5.1 \%$-Est6, Est6-1.8\%-Est 10-1.9\%-Est 4 and Est $6-3.0 \%$ Est 4 , do not establish a complete order but suggest that Est 10 is between Est 4 and Est6. These results, with data demonstrating apparent independent assortment of 67 other locus pairs, provide a foundation for establishing the frog genetic map.

KEY WORDS: electrophoretic variants; Rana pipiens; enzyme inheritance; linkage map.

The project was supported by Grant No. RR-00572 from the Division of Research Resources, National Institutes of Health. This paper is contribution No. C.87 from the Amphibian Facility, George W. Nace, Director.

${ }^{1}$ Department of Biology, The University of Texas System Cancer Center, M. D. Anderson Hospital and Tumor Institute, Houston, Texas 77030.

2 Division of Biological Sciences and Center for Human Growth and Development, University of Michigan, Ann Arbor, Michigan 48109. 


\section{INTRODUCTION}

In amphibians, as in all other organisms examined, allelic variants at a number of loci controlling the electrophoretic mobility of enzymes exist. The use of these electrophoretic variants is a powerful tool which, until now, has not been exploited for the formal study of genetic inheritance of these loci or to perform genetic linkage studies in amphibians. Many studies utilizing the variability of enzyme mobility of amphibians have been systematic or population studies examining large numbers of animals, sometimes for relatively few enzymes (Rogers, 1973; Dessauer et al., 1975, 1977; Guttman, 1975; Hedgecock, 1976; Case, 1978; Larson and Highton, 1978) or blood proteins (Platz and Platz, 1973). Genetic interpretations for electrophoretic variants have, for the most part, been based on analogy with similar systems in Drosophila or mammals.

A number of studies (Johnson and Chapman, 1971; Wright and Subtelny, 1971; Gallien et al., 1973; Wall and Blackler, 1974; Elinson, 1975) have taken advantage of the fact that closely related amphibian species have some electrophoretically distinguishable enzyme variants. Analysis of hybrid offspring enabled the examination of the expression of genes controlling the production of specific proteins during early embryogenesis. Where backcross hybrids were analyzed, the variants appeared to be inherited in a Mendelian manner as codominant alleles (Wright, 1975; Szymura and Farana, 1978). Only one study (Wright, 1975) suggested a possible linkage between glucose-6-phosphate dehydrogenase and 6-phosphogluconate dehydrogenase loci. Studies of this kind are limited to the enzymes which vary between species and by the frequent early lethality of hybrid embryos, precluding examination of enzymes or blood proteins fully expressed only in metamorphosed individuals.

Linkage relationships may be tested by crossing animals with genetic differences at two or more loci. The $F_{1}$ offspring are then backcrossed to one or both parents, and backcross offspring are analyzed for segregation and recombination of the genes of interest. Traditional genetic linkage studies of this sort in amphibians have been impeded by the relatively long generation times of many species and the lack of defined strains having identifiable genetic variants at multiple loci.

An alternative to production of sexually mature $F_{1}$ individuals and subsequent analysis of backcross hybrid offspring is the analysis of offspring of naturally occurring heterozygotes (Wright et al., 1976). In the present study we took advantage of enzyme polymorphisms in natural populations of the leopard frog, Rana pipiens. Using a screening procedure involving many different enzyme systems, we selected for experimental crosses individuals heterozygous at several loci. Individuals heterozygous at up to nine enzyme and protein loci were crossed with individuals of the same species homozygous 
at these loci. Thus, in a single generation, a formal analysis of the genetic inheritance of these loci was conducted simultaneously with a test cross to examine genetic linkage.

\section{MATERIALS AND METHODS}

\section{Screening Adults for Biochemical Variants}

A toe and a blood sample from five gravid females and one male Rana pipiens from each of two populations, Wisconsin and Vermont, were collected at the University of Michigan Amphibian Facility and shipped in dry ice to Houston. Blood was drawn from the musculocutaneous vein into a capillary tube and centrifuged to separate the blood cells and plasma.

Processing for electrophoretic analysis generally followed the procedures of Siciliano and Shaw (1976). Toes (approximately $0.1-0.2 \mathrm{~g}$ each) were minced on a glass plate resting on ice and homogenized by hand in a $1.0-\mathrm{ml}$ capacity glass homogenizer (Duall, Kontes). For each $0.1 \mathrm{~g}$ of tissue, $0.15 \mathrm{ml}$ of homogenizing buffer $(\mathrm{HM})$ consisting of $0.01 \mathrm{M}$ tris- $\mathrm{HCl}, p \mathrm{H} 7.5$, containing $0.001 \mathrm{M}$ EDTA and $0.001 \mathrm{~m} \beta$-mercaptoethanol was used. After the adults had produced progeny, a portion of the liver was removed and homogenized in $0.30 \mathrm{ml}$ of buffer per $0.1 \mathrm{~g}$ tissue. Homogenates were centrifuged at $15,000 \mathrm{~g}$ for $20 \mathrm{~min}$, and the supernatant fluids were subjected to vertical starch gel electrophoresis in either a tris-citrate (TC) buffer system, $p \mathrm{H} 7.0(0.13 \mathrm{M}$ tris $-0.043 \mathrm{M}$ citrate electrode buffer and 0.009 tris $-0.003 \mathrm{M}$ citrate in the gel), or a tris-versene-borate (TVB) buffer system, $p \mathrm{H} 8.0(0.5 \mathrm{M}$ tris $-0.016 \mathrm{M}$ EDTA- $-0.65 \mathrm{~m}$ borate electrode buffer and $0.05 \mathrm{M}$ tris- $0.0016 \mathrm{~m}$ EDTA- -0.065 $\mathrm{M}$ borate in the gel), Connaught starch (Fisher Scientific) at 90 or $95 \mathrm{~g} / 600 \mathrm{ml}$ gel buffer was used. Two drops of $\beta$-mercaptoethanol was added to the $600 \mathrm{ml}$ gel buffer mixture after boiling and degassing. The gel molds used are described in Siciliano and Shaw (1976).

After electrophoresis each gel was sliced to produce multiple gel slabs (six to eight from a 9.0-mm-thick gel) for enzyme staining. The enzymes examined in this preliminary screen are listed in Table $\mathrm{I}$. The procedures for staining are found in Siciliano and Shaw (1976) or Harris and Hopkinson (1976).

Blood samples were analyzed by slab polyacrylamide gel electrophoresis modified from the method of Davis (1964). Red blood cell samples were lysed by freezing and thawing. An equal volume of homogenizing buffer (HM) was added to the blood cells and the mixture centrifuged at $15,000 \mathrm{~g}$ for $20 \mathrm{~min}$. The pellet containing nuclei was discarded. Five microliters of blood cell extract or plasma was combined with $5 \mu \mathrm{l}$ of a mixture containing $0.125 \mathrm{M}$ tris- $\mathrm{HCl}$ buffer, $p \mathrm{H} 6.7,0.1 \mathrm{M} \beta$-mercaptoethanol, $20 \%$ glycerol, and $0.01 \%$ bromophenol blue and applied to sample slots in a slab gel $1.5 \mathrm{~mm}$ thick. The 
Table I. Protein Systems Tested for Variants

\begin{tabular}{|c|c|c|c|}
\hline Enzymes and abbreviations & E.C. number ${ }^{a}$ & Buffer system ${ }^{b}$ & Loci \\
\hline 1. Acid Phosphatase (AP) & 3.1.3.2 & $\mathrm{TC}$ & 3 \\
\hline 2. Aconitase (Acon) & 4.2.1.3 & $\mathrm{TC}$ & 2 \\
\hline 3. Adenylate kinase (AK) & 2.7.4.3 & TVB & 1 \\
\hline 4. Adenosine deaminase (ADA) & 3.5 .4 .4 & $\mathrm{TC}$ & 1 \\
\hline 5. Aldolase (Ald) & 4.1.2.7 & TVB & 2 \\
\hline 6. Creatine Kinase (CK) & 2.7.3.2 & TVB & 2 \\
\hline 7. Esterase (EST) & 3.1 .1 .1 & TC, TVB & 13 \\
\hline 8. Fumarase (Fum) & 4.2.1.2 & TVB & 1 \\
\hline 9. $\alpha$-Galactosidase $(\alpha-\mathrm{Gal})$ & 3.2 .1 .22 & TVB & 1 \\
\hline 10. Glucose-6-phosphate dehydrogenase (G6PD) & 1.1 .1 .49 & TVB & 1 \\
\hline 11. Glucosephosphate isomerase (GPI) & 5.3 .1 .9 & TVB & 2 \\
\hline 12. $\alpha$-Glucosidase $(\alpha$-GSD) & 3.2 .1 .20 & TVB & 3 \\
\hline 13. $\beta$-Glucosidase $(\beta$-GSD) & 3.2 .1 .21 & TVB & 3 \\
\hline 14. $\beta$-Glucuronidase $(\beta$-GUR) & 3.2 .1 .31 & TVB & 2 \\
\hline 15. Glutamate oxaloacetate transaminase (GOT) & 2.6.1.1 & TVB & 2 \\
\hline 16. Glyceraldehyde-3-phosphate dehydrogenase (G3PD) & 1.2.1.12 & $\mathrm{TC}$ & 1 \\
\hline 17. $\alpha$-Glycerophosphate dehydrogenase ( $\alpha$-GPD) & 1.1.1.8 & TVB & 2 \\
\hline 18. Glyoxalase I (Gly) & 4.4.1.5 & TVB & 1 \\
\hline 19. Glutathione reductase (GSR) & 1.6.4.2 & TVB & 1 \\
\hline 20. Hexosaminidase (HA) & 3.2 .1 .30 & TVB & 2 \\
\hline 21. Hexokinase $(\mathrm{HK})$ & 2.7 .1 .1 & TVB & 1 \\
\hline 22. Isocitrate dehydrogenase (IDH) & 1.1.1.42 & $\mathrm{TC}$ & 2 \\
\hline 23. Lactate dehydrogenase (LDH) & 1.1 .1 .27 & $\mathrm{TC}$ & 2 \\
\hline 24. Malate dehydrogenase (MDH) & 1.1 .1 .37 & $\mathrm{TC}$ & 2 \\
\hline 25. Malic enzyme (ME) & 1.1 .1 .40 & $\mathrm{TC}$ & 2 \\
\hline 26. Mannosephosphate isomerase (MPI) & 5.3.1.8 & TVB & 1 \\
\hline 27. $\alpha$-Mannosidase ( $\alpha$-Man) & 3.2 .1 .24 & TVB & 1 \\
\hline 28. Nucleoside phosphorylase (NP) & 2.4.2.1 & $\mathrm{TC}$ & 1 \\
\hline 29. Peptidase (PepLA and PepLGG) & 3.4.3.1 & TVB & 3 \\
\hline 30. 6-Phosphogluconate dehydrogenase (6PGD) & 1.1.1.44 & TC & 1 \\
\hline 31. Phosphoglucomutase (PGM) & 2.7 .5 .1 & $\mathrm{TC}$ & 3 \\
\hline 32. 2,3-Phosphoglycerate mutase (PGAM) & 5.4 .2 .1 & TVB & 2 \\
\hline 33. Tetrazolium oxidase (TO) & 1.15.1.1 & TVB or TC & 1 \\
\hline 34. Triosephosphate isomerase (TPI) & 5.3 .1 .1 & TVB or TC & 1 \\
\hline \multicolumn{4}{|l|}{ Blood proteins and abreviations } \\
\hline 35. Hemoglobin (Hb) & & PAGE & 2 \\
\hline 36. Albumin (Alb) & & PAGE & 1 \\
\hline
\end{tabular}

${ }^{a}$ E.C. number according to Commission on Biochemical Nomenclature (1972).

${ }^{b}$ Buffer system used for electrophoresis as abbreviated in text.

resolving gel contained $10 \%$ polyacrylamide (30 parts acrylamide, 0.8 part bisacrylamide) in $0.37 \mathrm{M}$ tris- $\mathrm{HCl}, p \mathrm{H} 8.9$. A $4 \%$ polyacrylamide stacking gel was used buffered with $0.125 \mathrm{~m}$ tris- $\mathrm{HCl}, p \mathrm{H}$ 6.7. The electrode buffer was $0.028 \mathrm{M}$ tris $-0.192 \mathrm{M}$ glycine, $p \mathrm{H}$ 8.3. Electrophoresis was at $100 \mathrm{~V}$ for approximately $4.5 \mathrm{hr}$. Positions of hemoglobins were marked by poking a hole in the gel or photography before fixation with $50 \%$ trichloroacetic acid and 
staining with $0.1 \%$ Coomassie blue. The gels were cleared by soaking in $5 \%$ methanol- $7 \%$ acetic acid.

\section{Analysis of Biochemical Variants in Offspring}

Adult animals with multiple heterozygous loci were chosen as parents and appropriate crosses were made. Fertilizations were done in vitro according to procedures described in Rugh (1962) and Nace et al. (1974). Offspring were reared through metamorphosis in Ann Arbor. Live juveniles were shipped to Houston. Animals were anesthetized in tricaine methanesulfonate (Finquel, Ayerst Laboratories), $0.2 \mathrm{mg} / \mathrm{ml}$. Sex was determined by inspection of the gonads under a dissecting microscope. Blood was collected from a cut in the heart ventricle in a heparinized glass capillary tube, diluted 1:1 in amphibian

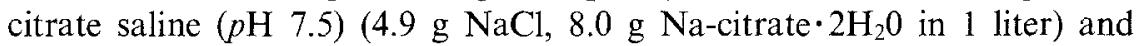
centrifuged at $300 \mathrm{~g}$. Blood cells were sometimes washed by resuspending in amphibian citrate saline.

Whole leg extracts of juvenile frogs were prepared in the same way as adult toe extracts. Liver was homogenized using a ratio of $1 \mathrm{~g}$ tissue to $4 \mathrm{ml}$ $\mathrm{HM}$ buffer ( $15 \mathrm{mg}$ liver to $60 \mu \mathrm{l} \mathrm{HM}$ ). Juvenile frog tissues were analyzed electrophoretically only for those proteins which were variant in one of the parents.

\section{Note on Nomenclature}

Several enzymes occurred as multiple isozymes. Isozymes were numbered so that the most anodal form was designated "1." The genetic locus controlling the isozyme is designated by the same number. This is consistent with the system generally used in the mouse. Exceptions to this rule are those systems for which a prior nomenclature has been established such as for the hemoglobins (Gillespie and Crenshaw, 1966). Alleles at a locus were assigned letters alphabetically. While the tendency was to call the most anodal form " $a$," the letter assignment in general reflects the order of discovery of an allelic form and not its relative mobility or its relative frequency. In some cases alleles are indicated as $a$ and $a^{\prime}$ or $b$ and $b^{\prime}$, indicating alleles having products with very close electrophoretic mobilities.

\section{RESULTS}

\section{Electrophoretic Patterns of Enzyme Variants}

The protein products of 72 different loci were examined (Table I). Eighteen of these showed electrophoretic variants, the details of these variants are discussed below. 

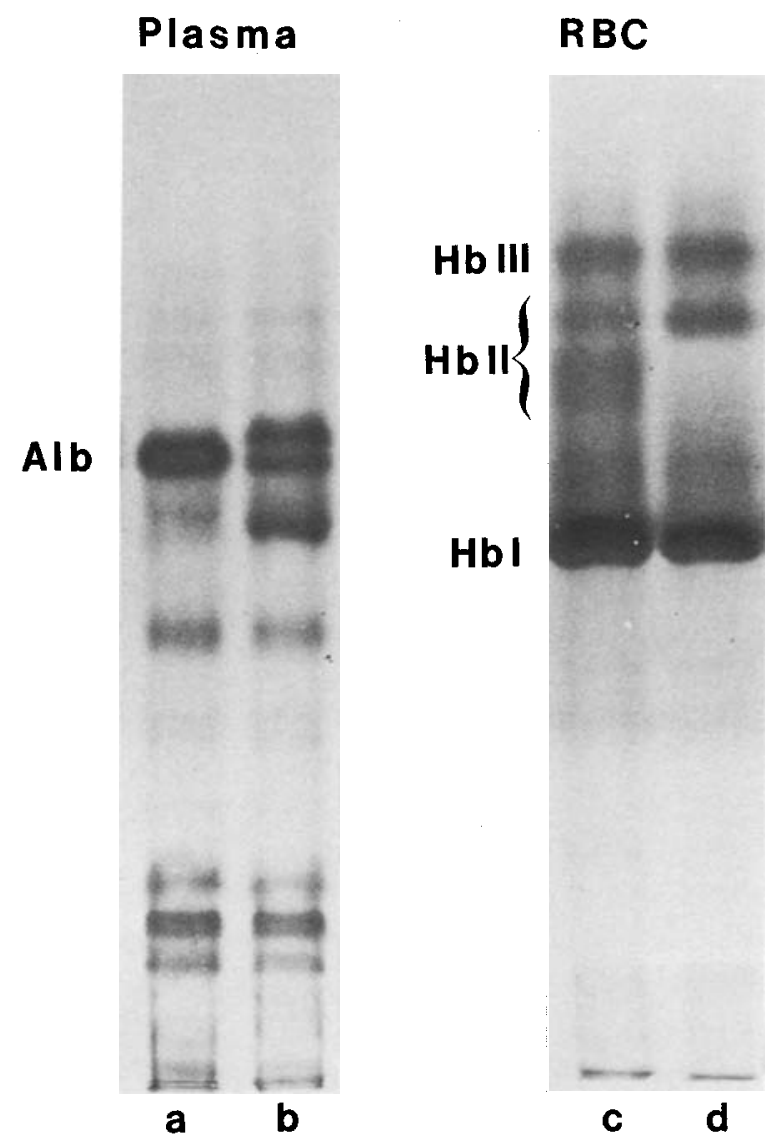

Fig. 1. Photographs of portions of a polyacrylamide gel stained for protein. Columns (a) and (b) show albumin genotypes $b^{\prime} / b$ and $a / b$, respectively, in plasma. Samples (c) and (d) are red cell lysates showing HBII genotypes $a / b$ and $a / a$, respectively.

Blood protein patterns produced by polyacrylamide gel electrophoresis (PAGE) are shown in Fig. 1. The product of the $b^{\prime}$ allele at the albumin ( $A l b$ ) locus has a slightly faster electrophoretic mobility than the product of the $b$ allele (Fig. 1a), while the $a$ allele product is still faster (Fig. 1b). Three hemoglobin zones are seen clearly after staining with Coomassie blue (Fig. $1 \mathrm{c}, \mathrm{d})$. $\mathrm{HbI}$ is the most abundant form. The genetic variant occurred in the $\mathrm{HbII}$ band. HbIIa is reduced in HbIl $a / b$ heterozygotes (Fig. 1c), and an HbII $b / b$ homozygote (not shown) has only the HbIIb band in this region. Hemoglobins $\mathrm{HbI}$ and $\mathrm{HbII}$ appear to correspond to those forms described by 
MPI

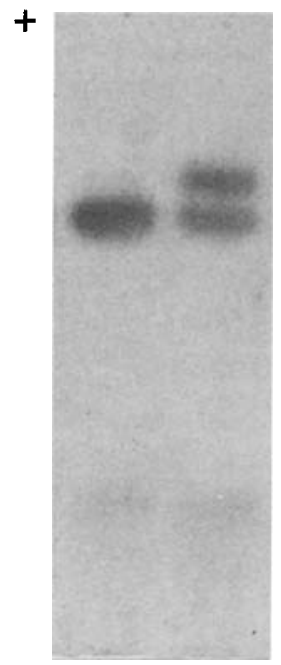

a

b
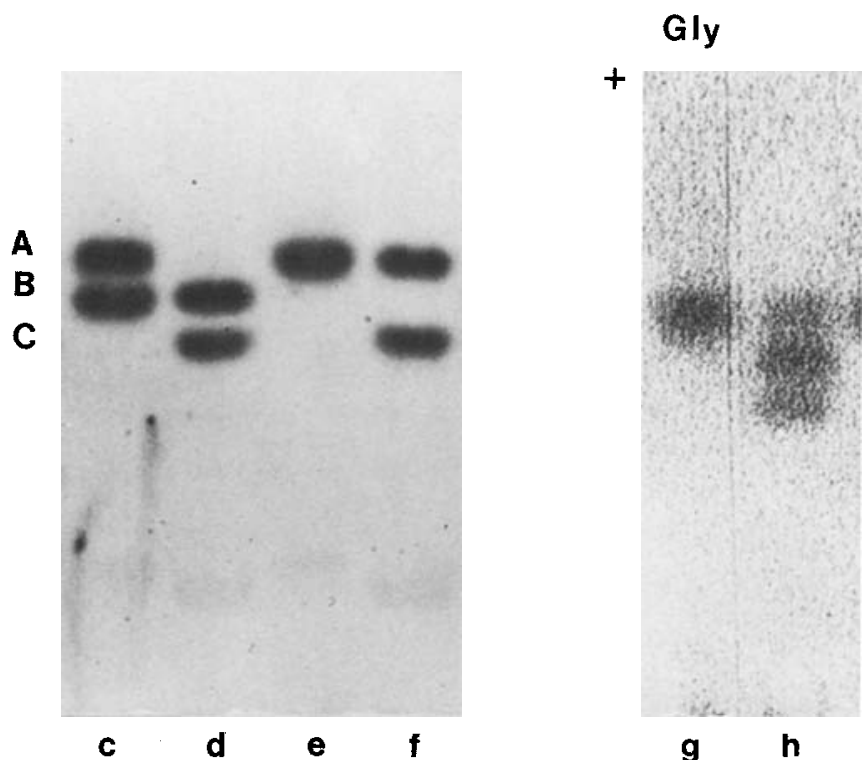

Fig. 2. Photographs of portions of starch gels stained for mannose- 6 -phosphate isomerase (MPI) or glyoxalase (Gly). MPI genotypes of samples (a) and (b) from cross 200 are (a) $b / b$ and (b) $a / b$ and of samples (c)-(f) from cross 600 are (c) $a / b$, (d) $b / c$, (e) $a / a$, (f) $a / c$. Gly genotypes (g)-(h) are (g) $a / a$ and (h) $a / b$.

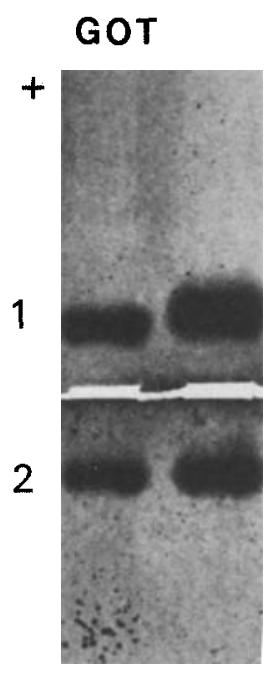

a

b
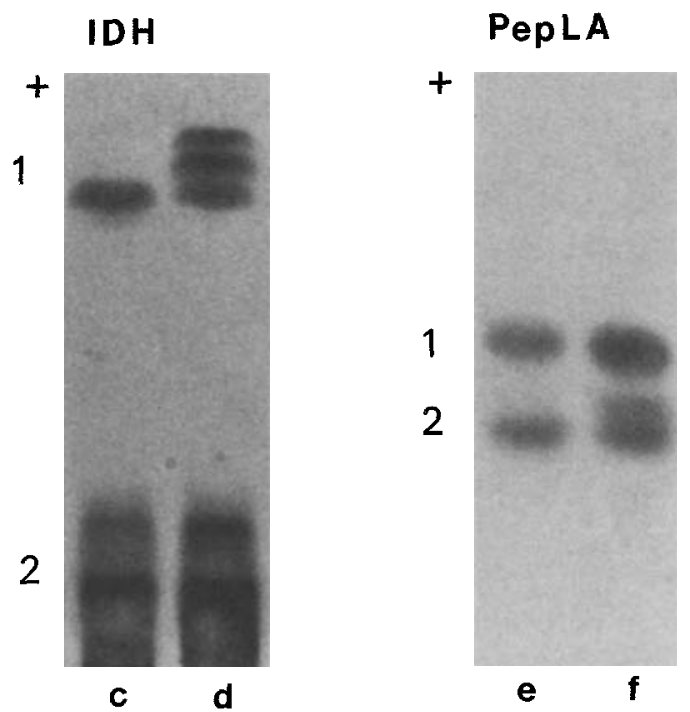

Fig. 3. Photographs of portions of starch gels stained for glutamate oxaloacetate transaminase (GOT), isocitrate dehydrogenase (IDH), and peptidase which cleaves the leucylalanine substrate (PepLA). GOTl genotypes are: (a) $b / b$ and (b) $a / b$; IDH 1 genotypes are (c) $b / b$ and (d) $a / b ;$ PepLA2 genotypes are: (e) $b / b$ and (f) $a / b$. 


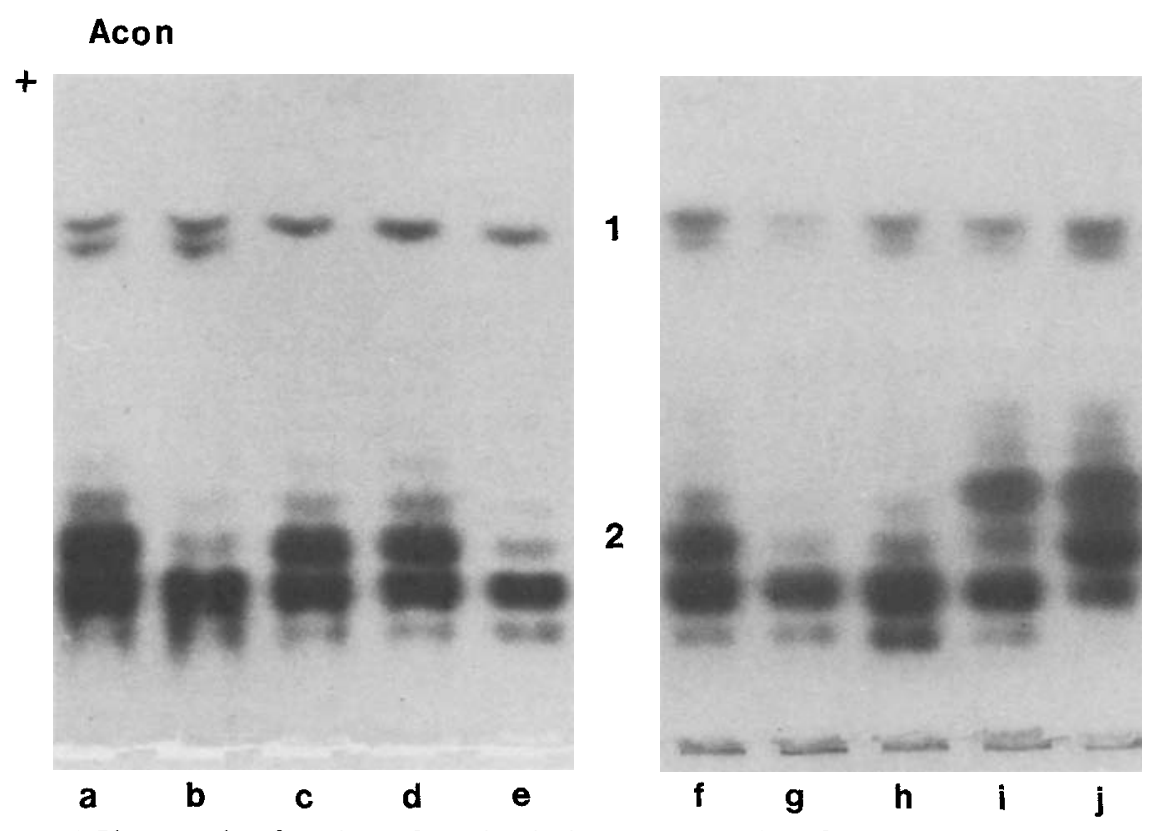

Fig. 4. Photographs of portions of starch gels showing segregation of alleles at aconitase (Acon1 and Acon2) loci. Samples (a) (e) are from cross 200, (f)-(j) from cross 300. The genotypes of the sample are (a) Aconl $a / b, A$ con $2 a / b$; (b) $A$ con $1 a / b$, Acon $2 b / b$; (c) Aconl $a / a, A c o n 2 a / b$; (d) Acon1 $a / a, A \operatorname{con} 2 a / b$; (e) $A \operatorname{con} 1 a / a, A \operatorname{con} 2 b / b$; (f) Acon $1 a / b, A \operatorname{con} 2 a / b$; (g) $A \operatorname{con} 1 a / b, A \operatorname{con} 2 b / b$; (h) $A \operatorname{con} 1 a / b, A \operatorname{con} 2 b / b$; (i) Acon1 $a / b$, Acon $2 c / b$; (j) Acon1 $a / b, A \operatorname{con} 2 c / a$.

Gillespie and Crenshaw (1966). HbIII is usually detectable only in newly metamorphosed animals and probably represents a larval hemoglobin. The genetic basis of the variations in albumin and $\mathrm{HbII}$ is verified by the pattern of inheritance seen in the offspring of the putative heterozygotes.

Several enzyme systems contain multiple isozymes. Evidence for the control of multiple isozymes by separate genetic loci in Rana pipiens is the heritable variation in the electrophoretic mobility in one form but constancy or independent variation in the other forms. Subunit composition can be deduced from the number of electrophoretic forms in heterozygotes. Most of the enzyme systems in the frog are similar to those reported in mammalian systems (Harris and Hopkinson, 1976) as to subunit composition and number of structural loci.

Mannosephosphate isomerase (MPI) and glyoxalase (Gly) in the frog are each coded for by a single genetic locus. MPI is a monomer so that heterozygotes produce only two forms (Fig. 2a,b). Gly is a dimer enzyme and produces a three-band pattern in heterozygotes (Fig. $2 \mathrm{~g}, \mathrm{~h}$ ). 


\section{PGM}

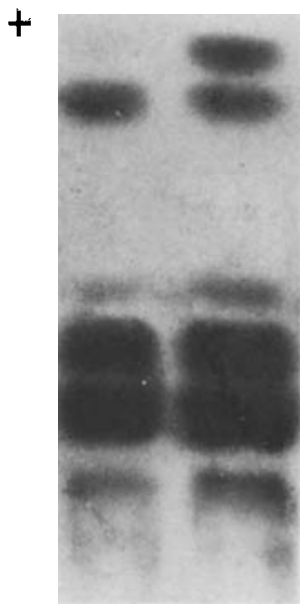

a

b

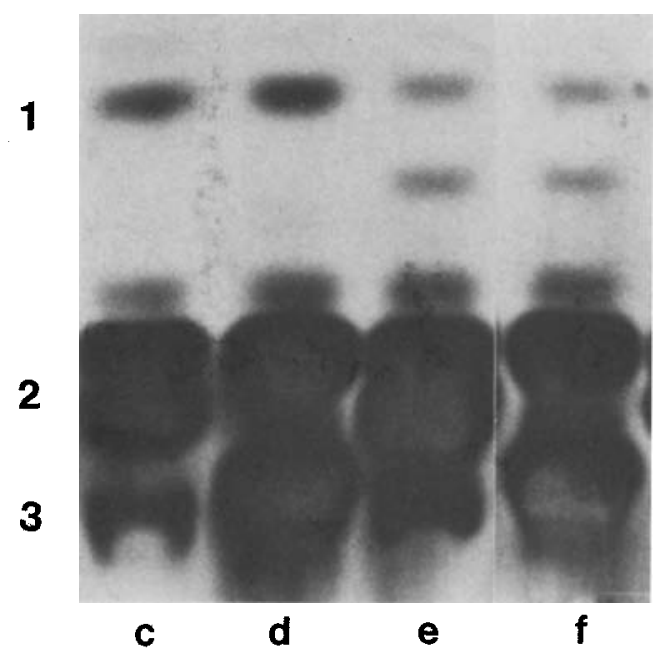

Fig. 5. Photographs of portions of starch gels stained specifically for phosphoglucomutase (PGM). Samples (a) and (b) are from cross 400, (c)-(f) from cross 500. The genotypes of the samples are (a) PGMI b/b, PGM2 a/b; (b) PGMI a/b, PGM2 $a / b$; (c) PGMIb/b, PGM $2 a / b$; (d) PGM1 b/b, PGM $2 a / d$; (e) PGM1b/d, PGM $2 a / b$; (f) $P G M 1 b / d, P G M 2 a / d$.

Glutamate oxaloacetate transaminase (GOT), isocitrate dehydrogenase (IDH), and peptidase, which cleaves the leucylalanine substrate (PepLA), are each coded for by two separate genetic loci, but in each of these cases a variant was found at only one locus (Fig. 3). Aconitase (Acon) also is coded for by two separate genetic loci and independent variants were found at both loci (Fig. 4). Phosphoglucomutase (PGM) and acid phosphatase (AP) are each coded for by three genetic loci and variants were found at two of the loci in each case (Figs. 5 and 6).

Esterases (Est) are detected using $\alpha$-napthyl esters. Examination of several tissues, blood cells, and plasma identified 13 esterase zones. Not all forms are found in all tissues and not all forms are resolved in each buffer system. The patterns seen in the leg extracts of offspring and toe extracts of the parents of one of the crosses are seen in Fig. 7. Variants reported here include Est 1 and Est5, both heterozygous in the male, and Est4, Est6, and Est10, heterozygous in the female. Use of two buffer systems and analysis of several tissues are required to resolve all of the esterase loci. A detailed analysis of esterase variants in $R$. pipiens will be published separately. 


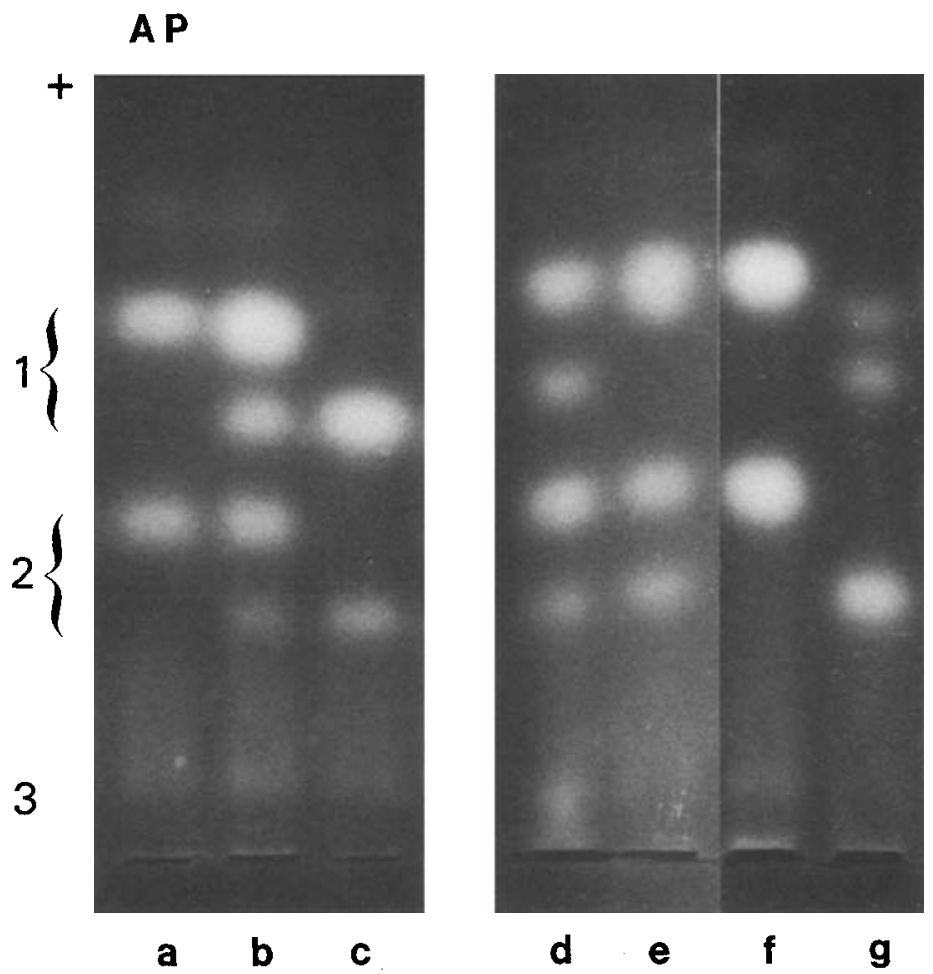

Fig. 6. Photograph of a starch gel stained for acid phosphatase (AP). Samples (a)-(c) are from cross 400 , (d)-(g) from cross 600 . The genotypes of the samples are (a) $A P 1 a / a, A P 2 a / a$; (b) $A P 1 a / b, A P 2 a / b$; (c) $A P 1 b / b, A P 2 b / b$; (d) $A P 1$ $a / b, A P 2 a / b$; (e) APl $a / a^{\prime}, A P 2 a / b$; (f) $A P 1 a / a, A P 2 a / a$; (g) APl $a^{\prime} / b, A P 2 b / b$.

\section{Inheritance of Enzyme Patterns}

The crosses made and the enzymes showing electrophoretic variants in the parents are listed in Table II. Allelic segregation data for each enzyme variant in each cross are shown in Tables III, IV, and V. Table III presents data on the inheritance of enzyme loci from a heterozygous female parent. Table IV contains data on the inheritance of enzyme loci from a heterozygous male parent. Both tables record the number of offspring of each genotype which inherit the alternative alleles from the heterozygous parent. Most crosses are of the test-cross type, yielding homozygotes and heterozygotes, as, for example, those involving the Aconl locus. Note that for Est5.the female parent was homozygous for the $b$ allele in cross 300 and the $a$ allele in cross 400 .

In other crosses a third allele is involved, but the inheritance of the 


\section{Est TVB}

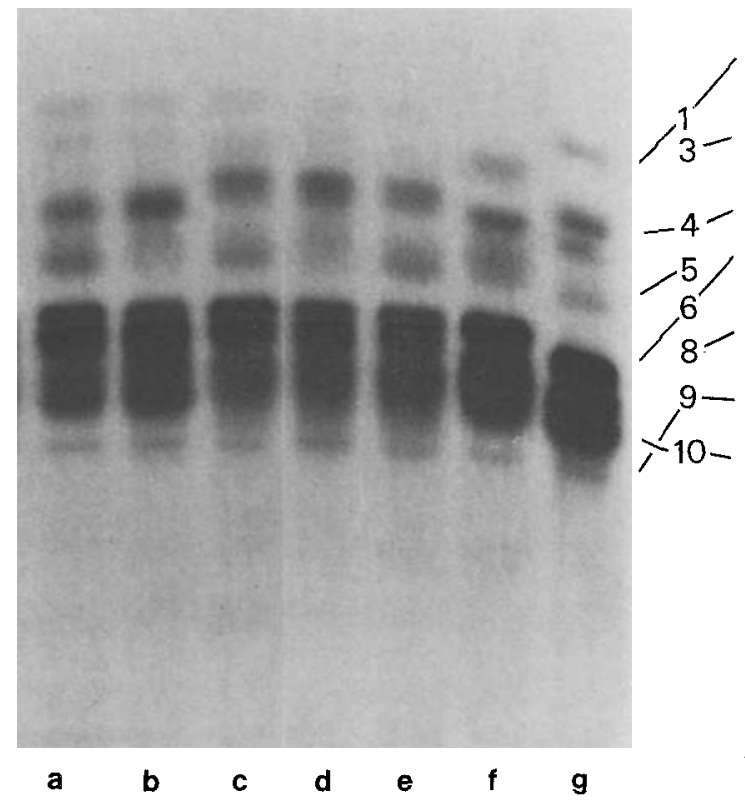

Est TC

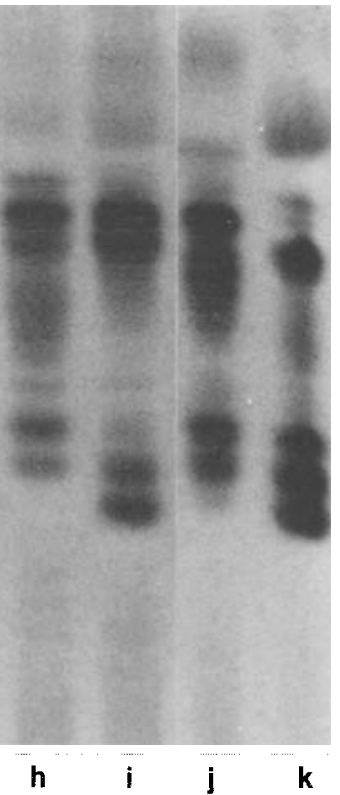

Fig. 7. Photographs of starch gels stained for esterases (Est) using $x$-naphthyl substrates. Columns (a)-(g) are from a starch gel using the TVB buffer system, columns (h)-(k), the TC buffer system. Columns (a)-(e) and (h)-(i) are from leg extracts of offspring of cross 300; columns (f) and (j) are toe extracts from the father of cross 300 , male 32699 , and columns (g) and (k) are toe extracts of the mother, female 31041. The positions of the various esterases are indicated by number. Est I, Est 4 , Est 5 are read on TVB, Est 6 and Est 10 on TC. Est 1 genotypes are (a) $a / b$, (b) $a / b$, (c) $a / c$, (d) $a / b$, (e) $a / c$, (f) $b / c$, (g) $a / a$. Est 4 genotypes are (a) $b / c$, (b) $b / c$, (c) $a / b$, (d) $a / b$, (f) $b / b$, (g) $a / c$. For Est 5 the genotypes are (a) $b / b$, (b) $a / b$, (c) $b / b$, (d) $a / b$, (e) $b / b$, (f) $a / b$, (g) $b / b$. Esto genotypes are (h) $a / d$, (i) $a / c$, (j) $a / a$, (k) $c / d$. Est 10 genotypes are (h) $b / b$, (i) $c / b$, (j) $b / b,(\mathrm{k}) c / b$.

alternative alleles of the heterozygous parent can be clearly distinguished. For example, the male in crosses 300,400 , and 600 was homozygous at the albumin $(A l b)$ locus $(b / b)$ while the three females were heterozygous $\left(a / b^{\prime}\right)$. Offspring were of two phenotypes $a / b$ and $b / b^{\prime}$. Other crosses of this type were Est4 (600), Est6 (200, 300, 400), Est10 (500), PGM2 (500), and Est1 (300).

Other crosses in which both parents are heterozygous but at least one allele is not shared enable the analysis of segregation of alleles in both parents. For example, in cross 600 the father was $a / b$ and the mother $a / c$ for MPI. Segregation of both parental sets of alleles can be distinguished. An $a / b$ heterozygote (Fig. 2c) must have received the $b$ allele from its father and the $a$ allele from its mother. Similarly a $b / c$ heterozygote (Fig. 2d) received the $b$ allele from its father and the $c$ from its mother. In an $a / a$ homozygote (Fig. 2e) both parents contributed an $a$ allele and an $a / c$ heterozygote (Fig. 2f) received 
Table II. Adult Frogs Heterozygous at Multiple Loci ${ }^{a}$

\begin{tabular}{|c|c|c|c|c|}
\hline \multirow{2}{*}{$\frac{\text { Animal No. }}{31040}$} & \multirow{2}{*}{$\frac{\text { Sex }}{\text { Female }}$} & \multicolumn{2}{|c|}{$\begin{array}{l}\text { Genotype } \\
\text { at heterozygous loci }\end{array}$} & \multirow{2}{*}{$\frac{\text { Parent in cross No. }}{200}$} \\
\hline & & $\begin{array}{l}\text { Aconl } a / b \\
\text { API } a / b \\
\text { AP2 } a / b \\
\text { Est4 } a / b \\
\text { Est5 } a / b\end{array}$ & $\begin{array}{l}\text { Est6 b/c } \\
\text { Est } 10 a / b \\
P G M I a / b \\
G O T 1 a / b\end{array}$ & \\
\hline 31041 & Female & $\begin{array}{l}\text { Acon } 2 c / b \\
\text { Alb } a / b^{\prime} \\
\text { Est } 4 a / b\end{array}$ & $\begin{array}{l}\text { Est6 c/d } \\
\text { Est } 10 \mathrm{clb} \\
\mathrm{HbII} a / b\end{array}$ & 300 \\
\hline 31042 & Female & $\begin{array}{l}\text { Aconl } a / b \\
\text { Alb } a / b^{\prime} \\
\text { APl } a / b \\
\text { AP2 } a / b \\
\text { Est } a / b\end{array}$ & $\begin{array}{l}\text { Est6 b/c } \\
I D H I a / b \\
\text { PepLA2 } 2 / b \\
\dot{P} G M 1 a / b\end{array}$ & 400 \\
\hline 31043 & Female & $\begin{array}{l}\text { API } a / b \\
\text { AP2 } a / b \\
\text { Est4 } a / b \\
\text { Est6 } a / b\end{array}$ & $\begin{array}{l}\text { Est } 10 \text { a/c } \\
\text { PGM } b / d \\
P G M 2 \text { b/d }\end{array}$ & 500 \\
\hline 31044 & Female & $\begin{array}{l}\text { Alb } a / b \\
\text { API } a / a^{\prime} \\
\text { AP2 } a / b \\
\text { Est4 } a / b \\
\text { Est5 } a / b\end{array}$ & $\begin{array}{l}\text { GOTI } a / b \\
\text { HBII } a / b \\
\text { MPI } a / c \\
\text { PepLA } a / b\end{array}$ & 600 \\
\hline 32699 & Male & $\begin{array}{l}\text { Acon2 } a / b \\
\text { APl } a / b \\
\text { AP2 } a / b \\
\text { Est } 1 b / c\end{array}$ & $\begin{array}{l}\text { Est5 } a / b \\
\text { Gly } a / b \\
\text { MPI } a / b\end{array}$ & $\begin{array}{c}200,300,400 \\
500,600\end{array}$ \\
\hline
\end{tabular}

${ }^{a}$ See Table I for description of abbreviations.

${ }^{b}$ At all other loci examined, these animals were homozygous.

the $a$ from the father and the $c$ from the mother. Others of this type are $A P I$ (600) and Acon2 (300).

Table V contains data on the inheritance of enzyme loci where both parents were heterozygous for the same two alleles, yielding data similar to an $\mathrm{F}_{2}$ cross. Loci in this category include $A P l$ in crosses 200,400 , and 500, $A P 2$ in crosses 200, 400, and 600, and Est 5 in crosses 200 and 600 . The similarity of numbers for $A P 1$ and $A P 2$ in crosses 200, 400, and 500 are accounted for by a very tight linkage. (See below.)

The data on segregation of all 18 of the variants whose inheritance was tested show no significant deviation $(p<0.01)$ from the expected normal Mendelian ratio. No sex linkage was detected.

\section{Evidence for Control of $A P 1$ and $A P 2$ by Closely Linked Separate Loci}

In cross 300 (Table IV) a male heterozygous at both $A P 1$ and $A P 2$ was 
Table III. Inheritance of Alleles in Offspring of Heterozygous Females $^{a}$

\begin{tabular}{|c|c|c|c|c|c|c|}
\hline \multirow[b]{2}{*}{ Locus } & \multirow[b]{2}{*}{ Cross } & \multicolumn{2}{|c|}{$\begin{array}{l}\text { Parental } \\
\text { genotypes }\end{array}$} & & \multirow[b]{2}{*}{ Offspring } & \multirow[b]{2}{*}{$x^{2}$} \\
\hline & & Female & Male & & & \\
\hline \multirow[t]{3}{*}{ Aconl } & 200 & $a / b$ & $a / a$ & & $46 a / a \quad 61 b / a$ & 2.10 \\
\hline & 400 & $a / b$ & $a / a$ & & $75 a / a \quad 62 b / a$ & 1.23 \\
\hline & & & & Total & $121 a / a 123 b / a$ & 0.02 \\
\hline \multirow{5}{*}{$\begin{array}{l}\text { Acon2 } \\
\text { Alb }\end{array}$} & 300 & $c / b$ & $a / b$ & & $56 c /-55 b /-$ & 0.009 \\
\hline & 300 & $b^{\prime} / a$ & $b / b$ & & $64 b^{\prime} / b \quad 46 a / b$ & 2.95 \\
\hline & 400 & $\mathrm{~b}^{\prime} / \mathrm{a}$ & $\mathrm{b} / \mathrm{b}$ & & $63 b^{\prime} / b \quad 79 a / b$ & 1.80 \\
\hline & 600 & $b^{\prime} / a$ & $b / b$ & & $65 b^{\prime} / b \quad 48 a / b$ & 2.56 \\
\hline & & & & Total & $192 b^{\prime} / b 173 a / b$ & 0.99 \\
\hline$A P I$ & 600 & $a / a^{\prime}$ & $a / b$ & & $64 a /-\quad 52 a^{\prime} /-$ & 1.24 \\
\hline Est 1 & 400 & $a / b$ & $b / c$ & & $69 b /-61 a /-$ & 0.49 \\
\hline \multirow[t]{5}{*}{ Est4 } & 200 & $a / b$ & $b / b$ & & $39 b / b \quad 41 a / b$ & 0.05 \\
\hline & 300 & $a / b$ & $b / b$ & & $62 b / b \quad 53 a / b$ & 0.70 \\
\hline & 500 & $a / b$ & $b / b$ & & $28 b / b \quad 24 a / b$ & 0.31 \\
\hline & 600 & $a / b$ & $b / b$ & & $45 b / b \quad 58 a / b$ & 1.64 \\
\hline & & & & Total & $173 b / b 176 a / b$ & 0.03 \\
\hline \multirow[t]{4}{*}{ Est6 } & 200 & $b / c$ & $a / a$ & & $43 b / a \quad 39 c / a$ & 0.20 \\
\hline & 300 & $d / c$ & $a / a$ & & $48 d / a \quad 65 c / a$ & 2.56 \\
\hline & 400 & $b / c$ & $a / a$ & & $62 b / a \quad 68 c / a$ & 0.28 \\
\hline & 500 & $b / a$ & $a / a$ & & $28 b / a \quad 24 a / a$ & 0.31 \\
\hline \multirow[t]{3}{*}{ Est 10} & 200 & $a / b$ & $b / b$ & & $36 a / b \quad 30 b / b$ & 0.55 \\
\hline & 300 & $b / c$ & $b / b$ & & $60 c / b \quad 49 b / b$ & 1.11 \\
\hline & 500 & $a / c$ & $b / b$ & & $26 a / b \quad 26 c / b$ & 0.0 \\
\hline \multirow[t]{3}{*}{ GOTI } & 200 & $a / b$ & $b / b$ & & $50 a / b \quad 56 b / b$ & 0.34 \\
\hline & 600 & $a / b$ & $b / b$ & & $55 a / b \quad 61 b / b$ & 0.31 \\
\hline & & & & Total & $105 a / b 117 b / b$ & 0.65 \\
\hline$I D H I$ & 400 & $a / b$ & $b / b$ & & $85 a / b \quad 66 b / b$ & 2.39 \\
\hline$M P I$ & 600 & $a / c$ & $a / b$ & & $56 a /-59 c /-$ & 0.08 \\
\hline \multirow[t]{3}{*}{ PepLA2 } & 400 & $a / b$ & $b / b$ & & $61 a / b \quad 81 b / b$ & 2.82 \\
\hline & 600 & $a / b$ & $b / b$ & & $58 a / b \quad 58 b / b$ & 0.0 \\
\hline & & & & Total & $129 a / b \quad 139 b / b$ & 0.37 \\
\hline \multirow[t]{4}{*}{$P G M I$} & 200 & $a / b$ & $b / b$ & & $61 a / b \quad 54 b / b$ & 0.43 \\
\hline & 400 & $a / b$ & $b / b$ & & $80 a / b \quad 71 b / b$ & 0.54 \\
\hline & 500 & $b / d$ & $b / b$ & & $25 d / b \quad 27 b / b$ & 0.08 \\
\hline & & & & Total & $166-/ b \quad 152 b / b$ & 0.62 \\
\hline \multirow{4}{*}{$\begin{array}{l}P G M 2 \\
H b I I\end{array}$} & 500 & $b / d$ & $a / a$ & & $28 a / b \quad 24 a / d$ & 0.31 \\
\hline & 300 & $a / b$ & $a / a$ & & $50 a / a \quad 51 \mathrm{a} / \mathrm{b}$ & 0.01 \\
\hline & 600 & $a / b$ & $a / a$ & & $56 a / a \quad 57 a / b$ & 0.01 \\
\hline & & & & Total & $106 a / a 108 a / b$ & 0.02 \\
\hline
\end{tabular}

${ }^{a}$ See Table I for description of abbreviations. 
Table IV. Inheritance of Alleles in Offspring of Heterozygous Male

\begin{tabular}{|c|c|c|c|c|c|c|}
\hline \multirow[b]{2}{*}{ Locus } & \multirow[b]{2}{*}{ Cross } & \multicolumn{2}{|c|}{$\begin{array}{l}\text { Parental } \\
\text { genotypes }\end{array}$} & & \multirow[b]{2}{*}{ Offspring } & \multirow[b]{2}{*}{$\chi^{2}$} \\
\hline & & Female & Male & & & \\
\hline \multirow[t]{6}{*}{$\operatorname{Acon} 2^{a}$} & 200 & $b / b$ & $a / b$ & & $49 b / b \quad 48 a / b$ & 0.01 \\
\hline & 300 & $c / b$ & $a / b$ & & $60 b /-51 a /-$ & 0.73 \\
\hline & 400 & $b / b$ & $a / b$ & & $70 b / b \quad 66 a / b$ & 0.12 \\
\hline & 500 & $b / b$ & $a / b$ & & $19 b / b \quad 26 a / b$ & 1.09 \\
\hline & 600 & $b / b$ & $a / b$ & & $55 b / b \quad 58 a / b$ & 0.08 \\
\hline & & & & Total & $253 b /-249 a /-$ & 0.03 \\
\hline$A P l$ & 300 & $a / a$ & $a / b$ & & $64 a / a \quad 48 a / b$ & 2.29 \\
\hline$A P 2$ & 300 & $a / a$ & $a / b$ & & $64 a / a \quad 48 a / b$ & 2.29 \\
\hline \multirow[t]{3}{*}{ EstI } & 300 & $a / a$ & $b / c$ & & $48 a / b \quad 39 a / c$ & 0.93 \\
\hline & 400 & $a / b$ & $b / c$ & & $69-/ b \quad 63-/ c$ & 0.27 \\
\hline & & & & Total & $117-/ b \quad 102-/ c$ & 1.03 \\
\hline \multirow[t]{3}{*}{ Est5 } & 300 & $b / b$ & $a / b$ & & $44 b / b \quad 59 a / b$ & 2.18 \\
\hline & 400 & $a / a$ & $a / b$ & & $79 b / a \quad 57 a / a$ & 3.56 \\
\hline & & & & Total & $123 b /-116 a /-$ & 0.21 \\
\hline \multirow[t]{6}{*}{ Gly } & 200 & $a / a$ & $a / b$ & & $50 a / a \quad 65 a / b$ & 1.96 \\
\hline & 300 & $a / a$ & $a / b$ & & $47 a / a \quad 55 a / b$ & 0.63 \\
\hline & 400 & $a / a$ & $a / b$ & & $73 a / a \quad 68 a / b$ & 0.18 \\
\hline & 500 & $a / a$ & $a / b$ & & $27 a / a \quad 25 a / b$ & 0.08 \\
\hline & 600 & $a / a$ & $a / b$ & & $64 a / a \quad 51 a / b$ & 1.47 \\
\hline & & & & Total & $261 a / a 264 a / b$ & 0.02 \\
\hline \multirow[t]{6}{*}{$M P I$} & 200 & $b / b$ & $a / b$ & & $57 b / b \quad 59 a / b$ & 0.03 \\
\hline & 300 & $b / b$ & $a / b$ & & $50 b / b \quad 62 a / b$ & 1.29 \\
\hline & 400 & $b / b$ & $a / b$ & & $80 b / b \quad 65 a / b$ & 1.55 \\
\hline & 500 & $b / b$ & $a / b$ & & $18 b / b \quad 33 a / b$ & 4.41 \\
\hline & 600 & $a / c$ & $a / b$ & & $61 b /-54 a /-$ & 0.43 \\
\hline & & & & Total & $266 b /-273 a /-$ & 0.09 \\
\hline
\end{tabular}

${ }^{a}$ See Table I for description of abbreviations.

test-crossed to a female homozygous for the $a$ alleles at both loci. Among the 112 offspring analyzed, there were $64 A P 1 a / a, A P 2 a / a$; and $48 A P 1 a / b, A P 2$ $a / b$ and no recombinants ( $A P 1 a / a, A P 2 a / b$; or $A P 1 a / b, A P 2 a / a)$. In three other crosses $(200,400,500$, Table V) both parents were $A P 1 a / b, A P 2 a / b$. Among the combined 306 offspring, all were accounted for as $A P 1$ a/a, $A P 2$ 
Table V. Inheritance of Alleles, Both Parents Heterozygous

\begin{tabular}{|c|c|c|c|c|c|}
\hline \multirow[b]{2}{*}{ Locus } & \multirow[b]{2}{*}{ Cross } & \multicolumn{3}{|c|}{$\begin{array}{l}\text { Genotypes of } \\
\text { offspring }\end{array}$} & \multirow[b]{2}{*}{$\chi^{2}$} \\
\hline & & $a / a$ & $a / b$ & $b / b$ & \\
\hline \multirow[t]{4}{*}{$A p I^{a}$} & 200 & 23 & 68 & 23 & 4.24 \\
\hline & 400 & 28 & 72 & 43 & 2.16 \\
\hline & 500 & 12 & 29 & 8 & 2.31 \\
\hline & & 63 & 169 & 74 & 4.14 \\
\hline \multirow[t]{5}{*}{$A P 2$} & 200 & 23 & 68 & 23 & 4.24 \\
\hline & 400 & 28 & 72 & 43 & 3.16 \\
\hline & 500 & 12 & 29 & 8 & 2.31 \\
\hline & 600 & 33 & 55 & 28 & 0.74 \\
\hline & & $\overline{96}$ & $\overline{224}$ & $\overline{102}$ & 1.78 \\
\hline \multirow[t]{4}{*}{ Est 5} & 200 & 22 & 26 & 15 & 3.48 \\
\hline & 600 & 16 & 46 & 17 & 2.16 \\
\hline & & - & - & - & \\
\hline & & 38 & 72 & 32 & 0.54 \\
\hline
\end{tabular}

${ }^{a}$ See Table I for description of abbreviations.

$a / a ; A P 1 a / b, A P 2 a / b$; or $A P 1 b / b, A P 2 b / b$ (Fig. 6a,b,c). No recombinants were found.

Separate $A P$ loci are indicated by the independent variation of $A P I$ and $A P 2$ found in one of the females (31044) used in cross 600 (Table III). Originally, we believed that she was a recombinant type having one band in the $A P I(a / a)$ region and two in the $A P 2(a / b)$. Her pattern was the same as that of the offspring shown in Fig. 6e. However, among offspring of this female with a male having the $A P I a / b, A P 2 a / b$ phenotype as in Fig. 6d, four types of offspring were seen. These include those having the parental patterns (6d, 6e) and one homozygous for the $a$ alleles at both $A P 1$ and $A P 2$. The fourth type, seen in Fig. $6 \mathrm{~g}$, had the $A P I b$ allele of the father and an $A P I a^{\prime}$ allele having a slightly slower mobility than the $a$ allele product. This animal was also homozygous at the $A P 2$ locus with the normal $A P 2 b / b$ pattern. Seeing the $a^{\prime} / b$ phenotype also indicated that the broad band shown in Fig. 6e was actually an $A P 1 \quad a / a^{\prime}$ genotype. Only the four genotypes shown in Fig. $6 \mathrm{~d}-\mathrm{g}$ were found in the offspring of the 600 cross. Out of 116 , there were 33 AP1 $a / a, A P 2 a / a ; 24 A P 1 a / a^{\prime}, A P 2 a / b ; 31 A P 1 a / b, A P 2 a / b$; and 28 AP1 $a^{\prime} / b, A P 2 b / b$.

The tight linkage between the $A P 1$ and $A P 2$ loci made it possible to 
identify the parental contribution to the $A P I-2$ chromosomal genotype. AP1-2 a $a$ indicates $A P 1$ a AP2 a linked on the same chromosomes. Those shown in Figure 6d-g are as follows: (d) $A P I-2 a a$ from the mother, $b b$ from the father: (e) $a a$ from the father, $a^{\prime} b$ from the mother, (f) $a a$ from both parents: (g) $a^{\prime} b$ from the mother, $b b$ from the father.

\section{Linkage Analysis}

Frogs used as parents were heterozygous at six to nine loci each enabling the testing of many linkages. Since no recombination was found between $A P 1$ and $A P 2$, these loci are considered together for the purpose of tabulation as the complex, AP1-2. Progeny of female 31040, heterozygous for eight loci, including the $A P 1-2$ complex (Table II) could be tested for all possible linkages (between locus pairs), a total of 28 . These same animals could be tested for 15 linkages among the enzyme variants carried by the father. In this particular cross the father was heterozygous at two of the same loci as the mother.

The linkage analysis for 75 pairs of loci are presented in Table VI. The genotypes recorded for each animal at each locus were tabulated for each locus pair. Usually four genotypes, two parental and two recombinant, were found. For example, in a cross of GOT1 $a / b$, PepLA2 $a / b$ female with a GOT1 $b / b, P e p L A 2 b / b$ male, the offspring genotypes GOT1 $b / b$, PepLA2 $b / b$ plus GOTI $a / b$, Pep LA2 $a / b$ were combined as parentals and GOT1 a/b, PepLA2 $b / b$ and $G O T 1 b / b$, PepLA2 $a / b$ were combined as recombinants. The $\chi^{2}$ values were calculated based on numbers expected for independent assortment. Included in the data on linkage are the two types of homozygous offspring from crosses involving parents both heterozygous at that locus (Table V). For example, linkage of $A c o n l$ and $A P 1$ was tested by counting $A c o n l$ a/a, $A P I$ $a / a$ plus $A$ con $1 a / b, A P 1 b / b$ as parentals and $A$ con $1 a / a, A P 1 b / b$ plus $A c o n I$ $a / b, A P I a / a$ as recombinants. Offspring heterozygous at the $A P I$ locus from two heterozygous parents could not be used in linkage analysis since the source of the $a$ or $b$ allele could not be determined. The designations "parental" or "recombinant" are used arbitrarily since for most locus pairs the offspring did not include the parental genotypes, and, for those that did, the phase (coupling or repulsion) was not known. The statistically greater class was designated "parental" and the small class "recombinant." In this way both linkage and phase can be tested.

Using the significance level of $p<0.01$, three linkage groups were identified from these data (Fig. 8). Linkage group 1 includes the locus controlling the aconitase 1 isozyme (AconI) and the locus controlling serum albumin $(A l b)$, recombination fraction 0.190 . Linkage group 2 includes four loci, glyoxalase $(G l y)$, acid phosphatase $1(A P 1)$, acid phosphatase $2(A P 2)$, and 
Table VI. Linkage Analysis ${ }^{a}$

\begin{tabular}{|c|c|c|c|c|c|c|}
\hline Locus pair & Cross & "Parental" & "Recombinant" & $x^{2}$ & $P^{b}$ & R.F ${ }^{c}$ \\
\hline AconI-Alb & 400 & III & 26 & 52.7 & $p<000 I$ & 0.190 \\
\hline \multirow[t]{2}{*}{$A \operatorname{con} 1-A P 1-2$} & 400 & 32 & 40 & 0.89 & & \\
\hline & 200 & 19 & 27 & 1.39 & & \\
\hline Acon1-Est & 400 & 70 & 59 & 0.94 & & \\
\hline Aconl-Est4 & 200 & 38 & 32 & 0.51 & & \\
\hline \multirow[t]{2}{*}{ Acon1-Est6 } & 200 & 39 & 31 & 0.91 & & \\
\hline & 400 & 60 & 66 & 0.29 & & \\
\hline Aconl-Est 10 & 200 & 33 & 28 & 0.41 & & \\
\hline Aconl-GOT1 & 200 & 45 & 58 & 1.64 & & \\
\hline AconI-IDH & 400 & 67 & 72 & 0.18 & & \\
\hline Acon1-PepLA2 & 400 & 66 & 71 & 0.18 & & \\
\hline \multirow{2}{*}{ Acon $L-P G M I$} & 200 & 59 & 47 & 1.36 & & \\
\hline & 400 & 65 & 73 & 0.46 & & \\
\hline$A \operatorname{con} 2-A l b$ & 300 & 52 & 59 & 0.44 & & \\
\hline \multirow[t]{6}{*}{ Acon $2-A P 1-2$} & 200 & 23 & 17 & & & \\
\hline & 300 & 46 & 65 & & & \\
\hline & 400 & 42 & 25 & & & \\
\hline & 500 & 10 & 11 & & & \\
\hline & 600 & 56 & 56 & & & \\
\hline & Total $^{d}$ & 168 & 174 & 0.11 & & \\
\hline \multirow[t]{3}{*}{ Acon2-EstI } & 300 & 37 & 50 & & & \\
\hline & 400 & 66 & 62 & & & \\
\hline & Total $^{d}$ & 103 & 112 & 0.38 & & \\
\hline \multirow{4}{*}{$\begin{array}{l}\text { Acon } 2-E s t 4 \\
\text { Acon } 2-E s t 5\end{array}$} & 300 & 56 & 53 & 0.08 & & \\
\hline & 300 & 59 & 44 & 2.18 & $p>0.1$ & \\
\hline & 400 & 58 & 73 & 1.72 & & \\
\hline & Total $^{d}$ & 117 & 117 & 0.0 & & \\
\hline Acon2-Est 6 & 300 & 56 & 55 & 0.01 & & \\
\hline Acon $2-E s t 10$ & 300 & 57 & 54 & 0.08 & & \\
\hline \multirow[t]{6}{*}{$A \operatorname{con} 2-G l y$} & 200 & 44 & 53 & & & \\
\hline & 300 & 48 & 54 & & & \\
\hline & 400 & 53 & 76 & & & \\
\hline & 500 & 21 & 24 & & & \\
\hline & 600 & 61 & 51 & & & \\
\hline & Total $^{d}$ & 227 & 258 & 1.98 & & \\
\hline \multirow[t]{6}{*}{$A \operatorname{con} 2-M P I$} & 200 & 52 & 45 & & & \\
\hline & 300 & 59 & 52 & & & \\
\hline & 400 & 37 & 32 & & & \\
\hline & 500 & 19 & 26 & & & \\
\hline & 600 & 48 & 42 & & & \\
\hline & Total $^{d}$ & 215 & 197 & 0.79 & & \\
\hline
\end{tabular}


Table VI. Continued

\begin{tabular}{|c|c|c|c|c|c|c|}
\hline Locus pair & Cross & "Parental", & "Recombinant" & $x^{2}$ & $P^{b}$ & R.F. \\
\hline Acon $2-H b I I$ & 300 & 53 & 47 & 0.36 & & \\
\hline \multirow[t]{2}{*}{$A l b-A P l-2$} & 400 & 31 & 38 & 0.71 & & \\
\hline & 600 & 68 & 45 & 4.68 & $p>0.03$ & \\
\hline$A l b-E s t l$ & 400 & 76 & 54 & 3.72 & $p \sim 0.05$ & \\
\hline \multirow[t]{2}{*}{$A l b-E s t 4$} & 300 & 57 & 53 & 0.15 & & \\
\hline & 600 & 49 & 52 & 0.09 & & \\
\hline$A l b-G O T 1$ & 600 & 64 & 49 & 1.99 & $p \sim 0.15$ & \\
\hline$A l b-I D H I$ & 400 & 69 & 71 & 0.03 & & \\
\hline$A l b-M P I$ & 600 & 57 & 55 & 0.04 & & \\
\hline \multirow[t]{2}{*}{$A l b-P e p L A 2$} & 400 & 75 & 67 & 0.45 & & \\
\hline & 600 & 44 & 67 & 4.77 & $p \sim 0.03$ & \\
\hline$A l b-P G M I$ & 400 & 84 & 58 & 4.76 & $p \sim 0.03$ & \\
\hline \multirow[t]{2}{*}{$A l b-H b I I$} & 300 & 52 & 49 & 0.09 & & \\
\hline & 600 & 54 & 60 & 0.32 & & \\
\hline$A P 1-2-E s t 1$ & 300 & 45 & 42 & 0.10 & & \\
\hline AP1-2-Est4 & 600 & 49 & 54 & 0.24 & & \\
\hline \multirow{3}{*}{ API-2-Est 5} & 300 & 100 & 6 & & & \\
\hline & 400 & 63 & 5 & & & \\
\hline & Total $^{d}$ & $\overline{163}$ & $\overline{I I}$ & 132.78 & $p<0.0001$ & 0.063 \\
\hline \multirow[t]{3}{*}{ APl-2-Est 6} & 200 & 16 & 18 & 0.12 & & \\
\hline & 400 & 29 & 35 & 0.56 & & \\
\hline & 500 & 13 & 10 & 0.39 & & \\
\hline \multirow[t]{2}{*}{ AP1-2-Est 10} & 200 & 12 & 11 & 0.04 & & \\
\hline & 500 & 11 & 11 & 0.00 & & \\
\hline \multirow[t]{6}{*}{$A P_{I-2-G l y}$} & 200 & 38 & 8 & & & \\
\hline & 300 & 77 & 25 & & & \\
\hline & 400 & 57 & 14 & & & \\
\hline & 500 & 18 & 4 & & & \\
\hline & 600 & 90 & 24 & & & \\
\hline & Total $^{d}$ & $\overrightarrow{280}$ & $\overline{75}$ & II 8.38 & $p<0.00 I$ & $0.21 I$ \\
\hline \multirow[t]{2}{*}{$A P 1-2-G O T I$} & 200 & 16 & 29 & 3.76 & $p \sim 0.05$ & \\
\hline & 600 & 61 & 55 & 0.31 & & \\
\hline$A P 1-2-I D H$ & 400 & 48 & 32 & 3.20 & $p>0.06$ & \\
\hline \multirow[t]{6}{*}{$A P I-2-M P I$} & 200 & 32 & 14 & & & \\
\hline & 300 & 54 & 58 & & & \\
\hline & 400 & 32 & 39 & & & \\
\hline & 500 & 11 & 12 & & & \\
\hline & 600 & 57 & 57 & & & \\
\hline & Total $^{d}$ & 186 & 180 & 0.10 & & \\
\hline \multirow[t]{2}{*}{$A P 1-2-P e p L A 2$} & 400 & 38 & 30 & 0.94 & & \\
\hline & 600 & 62 & 52 & 0.88 & & \\
\hline \multirow{3}{*}{$A P 1-2-P G M 1$} & 200 & 33 & 40 & 0.67 & & \\
\hline & 400 & 19 & 27 & 1.39 & & \\
\hline & 500 & 13 & 9 & 0.73 & & \\
\hline
\end{tabular}


Table VI. Continued

\begin{tabular}{|c|c|c|c|c|c|c|}
\hline Locus pair & Cross & "Parental" & "Recombinant" & $x^{2}$ & $p^{b}$ & R.F. \\
\hline \multirow{4}{*}{$\begin{array}{l}\text { API-2-HbII } \\
\text { Est I-Est5 }\end{array}$} & 600 & 53 & 61 & 0.56 & & \\
\hline & 300 & 41 & 38 & & & \\
\hline & 400 & 52 & 67 & & & \\
\hline & Total $^{d}$ & $\overline{93}$ & $\overline{105}$ & 0.73 & & \\
\hline \multirow{4}{*}{$\begin{array}{l}\text { EstI-Est6 } \\
\text { Est } I-G l y\end{array}$} & 400 & $\boldsymbol{H I I}$ & 6 & 94.23 & $p<0.000 I$ & $0.05 I$ \\
\hline & 300 & 43 & 36 & & & \\
\hline & 400 & 72 & 57 & & & \\
\hline & Total $^{d}$ & 115 & 93 & 2.33 & $p>0.1$ & \\
\hline Est $I-I D H I$ & 400 & 71 & 57 & 1.53 & & \\
\hline EstI-PGMI & 400 & 73 & 59 & 1.48 & & \\
\hline \multirow[t]{4}{*}{ Est4-Est6 } & 200 & 78 & 3 & & & \\
\hline & 300 & 107 & 2 & & & \\
\hline & 500 & 50 & 2 & & & \\
\hline & Total ${ }^{e}$ & 235 & 7 & 214.8 & $p<0.000 I$ & 0.030 \\
\hline \multirow{4}{*}{ Est4-Estio } & 200 & 52 & 2 & & & \\
\hline & 300 & 109 & 1 & & & \\
\hline & 500 & 51 & 1 & & & \\
\hline & Total $^{e}$ & 212 & 4 & 200.3 & $p<0.0001$ & 0.019 \\
\hline \multirow[t]{2}{*}{ Est4-GOTI } & 200 & 48 & 41 & 0.55 & & \\
\hline & 600 & 52 & 51 & 0.01 & & \\
\hline Est4-MPI & 600 & 55 & 48 & 0.48 & & \\
\hline Est4-PepLA2 & 600 & 59 & 45 & 1.88 & & \\
\hline Est4-HbII & 600 & 50 & 50 & & & \\
\hline \multirow[t]{2}{*}{ Esi4-PGM1 } & 200 & 42 & 37 & 0.32 & & \\
\hline & 500 & 26 & 25 & 0.02 & & \\
\hline Est4-PGM2 & 500 & 34 & 17 & 5.67 & $p<0.015$ & \\
\hline \multirow[t]{6}{*}{ Est $5-G l y$} & 200 & 30 & 7 & & & \\
\hline & 300 & 72 & 26 & & & \\
\hline & 400 & 104 & 34 & & & \\
\hline & 500 & 10 & 4 & & & \\
\hline & 600 & 22 & 11 & & & \\
\hline & Total $^{d}$ & $23^{8}$ & 82 & 76.05 & $p<0.000 I$ & 0.256 \\
\hline \multirow[t]{6}{*}{ Est $5-M P I$} & 200 & 17 & 20 & & & \\
\hline & 300 & 48 & 55 & & & \\
\hline & 400 & 70 & 67 & & & \\
\hline & 500 & 18 & 20 & & & \\
\hline & 600 & 17 & 15 & & & \\
\hline & Total $^{a}$ & 170 & 177 & 0.14 & & \\
\hline
\end{tabular}


Table VI. Continued

\begin{tabular}{|c|c|c|c|c|c|c|}
\hline Locus pair & Cross & "Parental" & "Recombinant" & $y^{2}$ & $P^{b}$ & R.F. \\
\hline \multirow[t]{4}{*}{ Est6-EstIo } & 200 & 65 & 0 & & & \\
\hline & 300 & 111 & 1 & & & \\
\hline & 500 & 47 & 3 & & & \\
\hline & Total $^{e}$ & 223 & 4 & 211.3 & $p<0.000 I$ & 0.018 \\
\hline Est6-PepLA & 400 & 71 & 58 & 1.31 & & \\
\hline \multirow[t]{2}{*}{ Est6-PGMI } & 200 & 51 & 42 & 0.87 & & \\
\hline & 400 & 69 & 61 & 0.49 & & \\
\hline Est6-PGM2 & 500 & 33 & 18 & 4.41 & $p>0.03$ & \\
\hline \multirow{2}{*}{ Est 10-PGMI } & 200 & 27 & 38 & 1.86 & & \\
\hline & 500 & 28 & 23 & 0.49 & & \\
\hline Est $10-P G M 2$ & 500 & 32 & 19 & 3.31 & $p>0.06$ & \\
\hline Est $10-H b I I$ & 300 & 56 & 44 & 1.44 & & \\
\hline \multirow[t]{6}{*}{$G l y-M P I$} & 200 & 55 & 60 & & & \\
\hline & 300 & 48 & 55 & & & \\
\hline & 400 & 72 & 69 & & & \\
\hline & 500 & 17 & 34 & & & \\
\hline & 600 & 62 & 54 & & & \\
\hline & Total $^{d}$ & 254 & 272 & 0.62 & & \\
\hline GOTI-MPI & 600 & 55 & 60 & 0.22 & & \\
\hline GOT1-PepLA2 & 600 & 57 & 58 & 0.01 & & \\
\hline GOTI-PGMI & 200 & 55 & 55 & 0 & & \\
\hline GOTI-HbII & 600 & 54 & 58 & 0.14 & & \\
\hline$I D H 1-P e p L A 2$ & 400 & 68 & 74 & 0.25 & & \\
\hline$I D H I-P G M I$ & 400 & 86 & 65 & 2.92 & $p>0.08$ & \\
\hline$M P I-P e p L A 2$ & 600 & 67 & 48 & 3.14 & $p>0.07$ & \\
\hline$M P I-H b I I$ & 600 & 57 & 55 & 0.04 & & \\
\hline PepLA2-PGMI & 400 & 73 & 68 & 0.18 & & \\
\hline PepLA2-HbII & 600 & 55 & 56 & 0.01 & & \\
\hline$P G M 1-P G M 2$ & 500 & 27 & 25 & 0.08 & & \\
\hline
\end{tabular}

${ }^{a}$ Boldface italics are used to indicate linked loci. Data for analysis of linkage pairs in fewer than 40 individuals are not included. See Table I for description of abbreviations.

${ }^{b}$ Probabilities ( $p$ ) are entered for $\chi^{2}$ values greater than 2 .

${ }^{c}$ Recombination frequencies (R.F.) were calculated only for data having a probability $(p)$ less than 0.01 of being due to chance.

${ }^{d}$ Total indicates totals for crosses where the locus pairs being tested are in the same individual male crossed with different females.

${ }^{e}$. Total indicates locus pairs being tested were in different individual females used for several crosses.

esterase $5(E s t 5)$. The recombination frequencies between these loci established their order: $G l y-A p 1-2,0.211 ; A P I-A P 2,0.00 ; A P I-2-E s t 5,0.063$; Gly-Est $5,0.256$. The order of $A P 1$ and $A P 2$ in the complex $A P 1-2$ will not be known until recombinants are found between these closely linked loci. Link- 

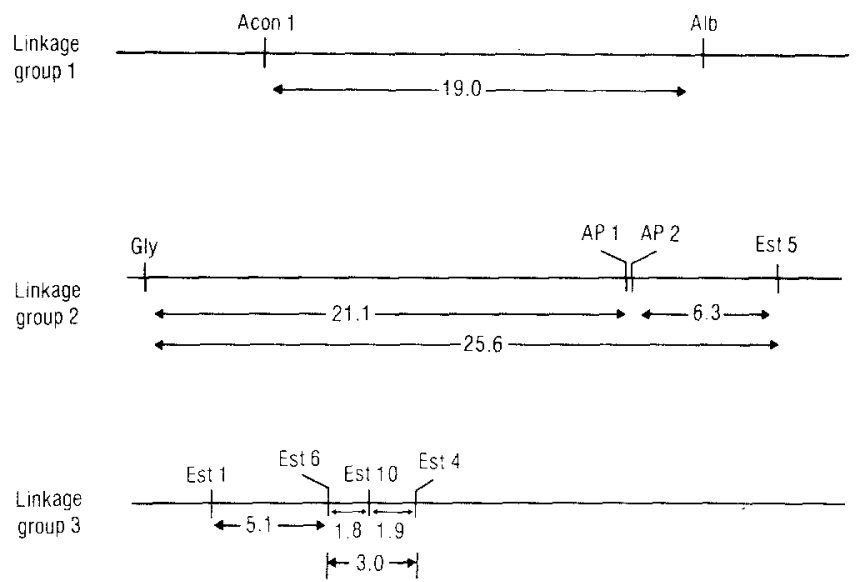

Fig. 8. Linkage maps for linkage groups 1,2, and 3. Relative distances between loci are in percent recombination.

age group 3 contains four esterase loci. The data show the relationships: Est $1-5.1 \%-$ Est 6, Est $6-1.8 \%-E s t 10-1.9 \%-E s t 4$ and Est $6-3.0 \%-$ Est 4 . Since all linkage pairs were not testable in the present series of crosses, the order of the loci is not determined except that Est 10 is probably between Est 6 and Est4. Further work on this linkage group is in progress.

Examination of the data in Table VI suggests independent assortment of the remaining loci with only a few exceptions. Of particular interest is the possibility that, with additional data, $P G M 2$ may map in linkage group 3 with Est 4, Est6, and Est 10. Other locus pairs to be followed in future crosses for a loose linkage relationship are IDH1-PGM1, MPI-PepLA2, Alb-Est1, $A l b-P G M 1$, and $A P I-2-I D H 1$ with $p$ values $<0.1$.

\section{DISCUSSION}

The results reported here established the Mendelian inheritance of 18 electrophoretic enzyme or blood protein variants in Rana pipiens. This is not surprising, but it tends to validate the use of electrophoretic variants as gene products in population and taxonomic studies of Rana and related amphibians.

The method of using natural heterozygotes as parents in studies of enzyme inheritance and linkage circumvents requirements for defined laboratory stocks and production of $F_{1}$ and backcross hybrid generations. For a limited number of crosses these studies have yielded a surprisingly large amount of data! The efficiency of data collection depends on selection of potential parents with maximum numbers of heterozygous loci. The difficulty that the phase, coupling or repulsion, is unknown at the start is overcome by 
statistical evaluation of the data, setting high confidence limits. The procedures employed here might be used in other species with long generation times or those difficult to maintain as laboratory animals. With new procedures being published for detection of gene product variants, particularly for starch gel electrophoresis, this approach to genetics could be applied especially easily to those species having high average heterozygosities (Guttman, 1975; Fuerst et al., 1977).

Genetic mapping in amphibians has been very limited. Cowan and Lloyd (1975) constructed physical maps of lampbrush chromosomes of several species showing the position of centromeres, loops, and the nucleolar organizer. With the exception of the nucleolar organizer the locations of genes controlling biochemical or morphological traits on the physical chromosome maps of amphibians are unknown. A number of mutant genes, primarily pigment-pattern variants and developmental anomalies, have been described in amphibian species commonly used in the laboratory, namely the axolotl (Malacinski and Brothers, 1974), Xenopus laevis (Gurdon and Woodland, 1975), Rana pipiens (Browder, 1968, 1975), and R. nigromaculata (Nishioka, 1977). In only a single instance has linkage between two mutant genes been found (Humphrey, 1959, 1975). Analysis of gynogenetic offspring of heterozygous mothers has been used to map the distance between mutant genes and the kinetochore (Volpe, 1970; Nace et al., 1970), but the small number of mutants available limited the usefulness of this approach in mapping.

In Rana pipiens there are 13 pairs of chromosomes, $2 N=26$ (DiBerardino, 1962). With the present demonstration of ten loci in three linkage groups and the apparent independent assortment of eight other loci, it should be possible to map other variant loci in Rana pipiens, including the pigmentation genes kandiyohi $(K)$, burnsi $(B)$, and melanoid $(m)$, since enzyme polymorphisms occur in the same populations as these pigment mutants. It is expected that additional enzyme variants will be found by screening larger numbers of animals and in particular by sampling different populations. Enzyme loci which are apparently unlinked on the basis of recombination of approximately $50 \%$ may be found to be in the same linkage group if a locus is found that lies between them on the linkage map. Likewise, even the linkage groups defined here should be regarded as tentative since two of them could lie at opposite ends of a very large metacentric chromosome.

Whereas it is difficult to compare data on the genetics of unshared morphological traits, data on linkage relationships of enzyme loci in amphibians can be compared directly to linkage relationships of homologous loci in other vertebrates. Eventually a statement might be made concerning the conservation of linkages in evolution. Linkage data are available for enzyme loci in fish (Morizot et al., 1977; Siciliano and Wright, 1976) as well as mice (Green, 1975) and humans (King, 1975). Linkage homologies have been 
demonstrated between mouse and human chromosomes (Lalley et al., 1978). The linkage of albumin to aconitase- 1 in Rana pipiens is of special interest in comparing the linkage of genetic loci for each of these proteins in other species. Albumin variants have been described both in humans (Weitkamp et al., 1969) and in the mouse (Petras, 1972). Serum albumin has been assigned to mouse chromosome 5 linked to $P G M 1$ (Nichols et al., 1975). In Rana pipiens $A l b-P G M 1$ may show a loose linkage, as indicated earlier. Aconitase-1 variants have been found in the axolotl (Pavlick, 1976) and in humans (Slaughter et al., 1975). A human chromosome 9 assignment for the Aconl isozyme has been established (Povey et al., 1976). The cluster of esterases in Rana pipiens linkage group 3 is comparable to a cluster of esterases in mouse chromosome 8 (Green, 1975), rat linkage group V (Womack and Sharp, 1976), and linkage of two esterase loci in platyfish and swordtails (Siciliano and Wright, 1976).

It has recently been demonstrated that frogs have a major histocompatibility region relatively distant from the kinetochore (Roux and Volpe, 1975; Richards et al., 1980). It is of considerable evolutionary interest whether this locus might have linkage relationships to other loci, particularly for proteins analogous to those present in mammals (Klein, 1977). The glyoxalase gene in both humans and mice is linked to the major histocompatibility complex on chromosome 6 in humans (Giblett and Lewis, 1976) and chromosome 17 in mice (Meo et al., 1977; Leinwand et al., 1978). In the mouse both $\mathrm{H}-2$ and glyoxalase are linked to an acid phosphatase processing locus (Womack and Eicher, 1977). In humans two acid phosphatases $A C P 1$ and $A c P 2$ are located in chromosomes 2 and 11, respectively (King, 1975). These facts make the enzyme loci (Gly, Ap1, Ap2, Est5) in our linkage group two very interesting. Methods have been derived to test the linkage of enzyme variants to the major histocompatibility complex using skin grafting from mothers to their gynogenetic progeny to identify gynogenetic animals homozygous and heterozygous for the major histocompatibility complex. Further investigation will determine whether the major histocompatibility region in the frog is included in this linkage group.

\section{ACKNOWLEDGMENTS}

The authors thank Dr. James H. Asher, Jr., whose discussions of genetic inheritance in Rana pipiens provided the impetus for this study. We thank Dr. Donald C. Morizot for critically reading the manuscript. The technical assistance of Ms. Gretchen Hazen, Ms. Reta J. Haynes, Ms. Li-hua Wong, and Ms. Renee Shapiro is gratefully acknowledged.

\section{REFERENCES}

Browder, L. W. (1968). Pigmentation in Rana pipiens. I. Inheritance of the speckle mutation. $J$. Hered. 59:162. 
Browder, L. W. (1975). Frogs of the genus Rana. In King, R. C. (ed.), Handbook of Genetics, Vol. 4, Plenum Press, New York, pp. 19-33.

Case, S. M. (1978). Biochemical systematics of members of the genus Rana native to western North America. Syst. Zool. 27:299.

Commission on Biochemical Nomenclature (1972). Enzyme Nomenclature, Elsevier, Amsterdam, $443 \mathrm{pp}$.

Cowan, H. G., and Lloyd, L. (1975). Working maps of the lampbrush chromosomes of amphibia. In King, R. C. (ed.), Handbook of Genetics, Vol. 4, Plenum Press, New York, pp. 57-77.

Davis, B. J. (1964). Disc electrophoresis. II. Method and application to Human serum proteins. Ann. N.Y. Acad. Sci. 121:404.

Dessauer, H. C., Nevo, E., and Chuang, K. C. (1975). High genetic variability in an ecologically variable vertebrate, Bufo viridus. Biochem. Genet. 13:651-661.

Dessauer, H. C., Gartside, D. F., and Zweifel, R. G. (1977). Protein electrophoresis and the systematics of some New Guinea hybrid frogs (genus Litoria). Syst. Zool. 26:426.

DiBerardino, M. A. (1962). The karyotype of Rana pipiens and investigation of its stability during embryonic differentiation. Dev. Biol. 5:101.

Elinson, R. P. (1975). Isozymes and morphology of five amphibian hybrid combinations which develop beyond gastrulation. Can. J. Zool. 53:993.

Ferguson-Smith, M. A., Newman, B. F., Ellis, P. M., Thompson, D. M. G., and Riley, I. D. (1973). Assignment by deletion of human red cell acid phosphatase gene locus to the short arm of chromosome 2. Nature New Biol. 243:271.

Fuerst, P. A., Chakraborty, R., and Nei, M. (1977). Statistical studies on protein polymorphism in natural populations. I. Distribution of single locus heterozygosity. Genetics 86:455.

Gallien, C., Aimar, C., and Guillet, F. (1973). Nucleocytoplasmic interactions during ontogenesis in individuals obtained by intra and interspecific nuclear transplantation in the genus Pleurodeles (Urodele Amphibian): Morphology, analysis of two enzymatic systems (LDH and MDH) and immunity reactions. Dev. Biol. 33:154.

Giblett, E. R., and Lewis, M. (1976). Gene linkage studies on glyoxalase I. Cytogenet. Cell Genet. 16:313.

Gillespie, J. H., and Crenshaw, J. W. (1966). Hemoglobin variation in Rana pipiens. Copeia 1966:889.

Green, M. C. (1975). The laboratory mouse, Mus musculus. In King, R. C. (ed.), Handbook of Genetics, Vol. 4: Vertebrates of Genetic Interest, Plenum Press, New York, pp. $203-241$.

Gurdon, J. B., and Woodland, H. R. (1975). Xenopus. In King, R. C. (ed.), Handbook of Genetics, Vol. 4: Vertebrates of Genetic Interest, Plenum Press, New york.

Guittman, S. I. (1975). Genetic variation in the genus Bufo. II. Isozymes in northern allopatric populations of the American toad Bufo americanus. In Markert, C. (ed.), Isozymes IV: Genetics and Evolution, Academic Press, New York, pp. 679-796.

Harris, H., and Hopkinson, D. A. (1976). Handbook of Enzyme Electrophoresis in Human Genetics, North-Holland, Amsterdam.

Hedgecock, D. (1976). Genetic variation in two widespread species of salamanders, Taricha granulosa and Taricha torosa. Biochem. Genet. 14:561.

Humphrey, R. R. (1959). A linked gene determining the lethality usually accompanying a hereditary fluid imbalance in the Mexican axolotl. J. Hered. 50:279.

Humphrey, R. R. (1975). The axolotl Ambystoma mexicanum. In King, R. C. (ed.), Handbook of Genetics, Vol. 4, Plenum Press, New York, pp. 3-17.

Johnson, K. E., and Chapman, V. M. (1971). Expression of paternal genes during embryogenesis of viable interspecific hybrid embryo Rana pipiens $\times$ Rana palustris-Electrophoretic analysis of five enzyme systems. $J$. Exp. Zool. 178:313.

King, R. C. (1975). Gene localizations and other properties of human chromosomes. In King, R. C. (ed.), Handbook of Genetics, Vol. 4: Vertebrates of Genetic Interest, Plenum Press, New York, pp. 537-544.

Klein, J. (1977). Evolution and function of the major histocompatibility system: Facts and speculations. In Gotze, D. (ed.), The Major Histocompatibility System in Man and Animals, Springer-Verlag, New York, pp. 339-378.

Lalley, P. A., Minna, J. D., and Francke, U. (1978). Conservation of autosomal gene synteny groups in mouse and man. Nature 274:160. 
Larson, A., and Highton, R. (1978). Geographic protein variation and divergence in the salamanders of the Plethodon welleri group. Syst. Zool. 27:431.

Leinwand, L., Nichols, E., and Ruddle, F. H. (1978). Assignment of the gene for glyoxalase I to mouse chromosome 17 by somatic cell genetics. Biochem. Genet. 16:659-666.

Malacinski, G. M., and Brothers, A. J. (1974). Mutant genes in the Mexican axolotl. Science 184: 1142 .

Meo, T., Douglas, T., and Rijnbeek, A. (1977). Glyoxalase I polymorphism in the mouse: A new genetic marker linked to $H$-2. Science 198:311.

Morizot, D. C., Wright, D. A., and Siciliano, M. J. (1977). Three linked enzyme loci in fishes: Implications in the evolution of vertebrate chromosomes. Genetics 86:645.

Nace, G. W., Richards, C. M., and Asher, J. H., Jr. (1970). Parthenogenesis and genetic variability. I. Linkage and inbreeding estimation in the frog, Rana pipiens. Genetics 66:349.

Nace, G. W., Culley, D. D., Emmons, M. B., Gibbs, E. L., Hutchison, V. H., and McKinnell, R. G. (1974). Amphibians: Guidelines for the Breeding, Care and Management of Laboratory Animals, Subcommittee on Amphibian Standard ILAR (NAS/NRC) Washington, D.C.

Nichols, E. A., Ruddle, F. H., and Petras, M. L. (1975). Linkage of the locus for serum albumin in the house mouse, Mus musculus. Biochem. Genet. 13:551.

Nishioka, M. (1977). Color variants induced by radiation and their inheritance in Rana nigromaculata. Sci. Rep. Lab. Amphib. Biol. Hiroshima Univ. 2:25.

Pavlick, F. (1976). Variability and inheritance of isozyme patterns in the mexican axolotl. Am. Zool. 16:231.

Petras, M. L. (1972). An inherited albumin variant in the house mouse, Mus musculus. Biochem. Genet. 7:273.

Platz, J. E., and Platz, A. L. (1973). Rana pipiens complex: Hemoglobin phenotypes of sympatric and allopatric population in Arizona. Science 179:1334.

Povey, M. S., Slaughter, C. A., Wilson, D. E., Gormley, I. P., Buckton, K. E., and Bobrow, M. (1976). Evidence for the assignment of the loci $A K_{l} A K_{3}$ and $A C O N_{S}$ to chromosome 9 in man. Ann. Hum. Genet. 39:413.

Richards, C. M., Nace, G. W., and Asher, J. H., Jr., (1980). Transplantation genetics in Rana pipiens using gynogenetic animals. Submitted for publication.

Rogers, J. S. (1973). Protein polymorphism, genic heterozygosity and divergence in the toads Bufo cognatus and B. speciosus. Copeia 1973:322.

Roux, K. H., and Volpe, E. P. (1975). Evidence for a major histocompatibility complex in the leopard frog. Immunogenetics $2: 577$.

Rugh, R. (1962). Experimental Embryology, Burgess, Minneapolis.

Siciliano, M. J., and Shaw, C. R. (1976). Separation and localization of enzymes of gels. In Smith, I. (ed.), Chromatographic and Electrophoretic Techniques, Vol. 2, 4th ed., William Heinemann Medical Books Ltd., London, pp. 184-209.

Siciliano, M. J., and Wright, D. A. (1976). Biochemical genetics of the platyfish-swordtail hybrid melanoma system. Prog. Exp. Tumor Res. 20:398.

Slaughter, C. A., Hopkinson, D. A., and Harris, H., (1975). Aconitase polymorphism in Man. Ann. Hum. Genet. 39:193.

Sparkes, R. S., Mohandas, T., Sparkes, M. C., and Shulkin, J. D. (1978). Aconitase (E.C. 4.2.1.3) mitochondrial locus mapped to human chromosome 22. Studies with Chinese hamsterhuman somatic cell hybrids. Biochem. Genet. 16:751.

Szymura, J. M., and Farana, I. (1978). Inheritance and linkage analysis of five enzyme loci in interspecific hybrids of toadlets, genus Bombina. Biochem. Genet. 16:307.

Volpe, E. P. (1970). Chromosome mapping in the leopard frog. Genetics 64:11.

Wall, D. A., and Blackler, A. W. (1974). Expression of lactate dehydrogenase phenotypes in intraspecific and interspecific matings of two species of Xenopus. Dev. Biol. 41:97.

Weitkamp, L. R., Franglen, G., Rokala, D. A., Polesky, H. F., Simpson, N. E., Sunderman, F. W., Jr., Bell, H. E., Saave, J., Lisker, R., and Bohls, S. W. (1969). An electrophoretic comparison of human serum albumin variants: Eight distinguishable types. Hum. Hered. 19:159.

Womack, J. E., and Eicher, E. M. (1977). Liver specific lysosomal acid phosphatase deficiency (Apl) on mouse chromosome 17. Mol. Gen. Genet. 155:315. 
Womack, J. E., and Sharp, M. (1976). Comparative autosomal linkage in mammals: Genetics of esterases in Mus musculus and Rattus norvegicus. Genetics 82:665.

Wright, D. A. (1975). Expression of enzyme phenotypes in hybrid embryos. In Markert, C. (ed.), Isozymes IV: Genetics and Evolution, Academic Press, New York, pp. 649-664.

Wright, D. A., and Subtelny, S. (1971). Nuclear and cytoplasmic contributions to dehydrogenase phenotypes in hybrid frog embryos. Dev. Biol. 24:119.

Wright, D. A., Huang, C. P., and Chuoke, B. D. (1976). Meiotic origin of triploidy in the frog detected by genetic analysis of enzyme polymorphisms. Genetics 84:319. 